\title{
GROWTH ASSESSMENT OF TROPICAL SUGARBEET AS INFLUENCED BY SPACING
}

\author{
M.A.T. Sohel*, M.A.E. Hossain, H.P. Roy, S.M. Reza, F.H. Shanta and M.R.R. Razib \\ Bangladesh Sugarcrop Research Institute, Ishurdi, Pabna. \\ Corresponding E-mail: atsohel@yahoo.com
}

(Received: 22 October, 2020, Accepted: 10 November, 2020)

Keywords: Germination, growth, spacing, sugarbeet

\begin{abstract}
The experiment was carried out at the research field of Agronomy and Farming Systems Division, Bangladesh Sugarcrop Research Institute (BSRI), Ishurdi, Pabna during 20122013 to determine the most suitable spacing for sugarbeet cultivation in Bangladesh. The experiment was conducted with nine spacing viz. $50 \mathrm{~cm} \times 20 \mathrm{~cm}, 60 \mathrm{~cm} \times 20 \mathrm{~cm}, 70 \mathrm{~cm}$ $\times 20 \mathrm{~cm}, 50 \mathrm{~cm} \times 25 \mathrm{~cm}, 60 \mathrm{~cm} \times 25 \mathrm{~cm}, 70 \mathrm{~cm} \times 25 \mathrm{~cm}, 50 \mathrm{~cm} \times 30 \mathrm{~cm}, 60 \mathrm{~cm} \times 30 \mathrm{~cm}$ and $70 \mathrm{~cm} \times 30 \mathrm{~cm}$ in a randomized complete block design with three replications. The effects of spacing on sugarbeet plantation were observed on growth and growth contributing components (germination percentage, number of leaves plant ${ }^{-1}$, root length, shoot length, root fresh weight, shoot fresh weight, root dry weight, shoot dry weight, crop growth rate) of sugarbeet. The highest germination percentage (95.67\%), number of leaves plant ${ }^{-1}(34.33)$ at 30 DAS, shoot length $(54.07 \mathrm{~cm})$ at 120 DAS, root fresh weight $\left(969.47 \mathrm{~g} \mathrm{plant}^{-1}\right)$ at $150 \mathrm{DAS}$, shoot fresh weight (752.47 $\left.\mathrm{g} \mathrm{plant}^{-1}\right)$ at $120 \mathrm{DAS}$ and other growth contributing parameters were obtained with the spacing $70 \mathrm{~cm} \times 30 \mathrm{~cm}$. However, the maximum root length $(38.97 \mathrm{~cm})$ was obtained with $50 \mathrm{~cm} \times 20 \mathrm{~cm}$ spacing. It was concluded that the wider spacing promoted the growth of individual beet, though the optimum spacing for maximum root growth of sugarbeet was $50 \mathrm{~cm} \times 20 \mathrm{~cm}$.
\end{abstract}

\section{Introduction}

Sugar is an important source of energy with glucose being the most important for the body. The brain requires around $130 \mathrm{~g}$ of sugar (glucose) per day to keep functioning. Food and Agriculture Organization (FAO) recommend to consume for a healthy man about $13 \mathrm{~kg}$ sugar per year, in a sense sugar is a part of our food habit (Patil and Patil, 2011). There are different types of sugar producing crops in the world like sugarcane, sugarbeet, date palm, palmyra palm, stevia etc. Sugarbeet (Beta vulgaris) is one of the most important crops in a temperate climates (Sohrabi and Heidari, 2008; AbdelMotagally and Attia, 2009). It ranks the second as sugar crop after sugarcane in the world. Sugarbeet is grown nearly in 40 countries and accounts for up to 40 to $45 \%$ of the total world sugar production (Shahl et al., 2000). Sugarbeet has an average sugar content of 14-20\% and optimal beet yield 80 to $100 \mathrm{t} \mathrm{ha}^{-1}$ for the tropical climates whereas $15 \%$ sugar and 40 to $60 \mathrm{t} \mathrm{ha}^{-1}$ beet yield for temperate climates (Syngenta, 2004). One hundred gram sugarbeet contains 42.68 kilocalories, $8 \mathrm{~g}$ carbohydrates, and $2 \mathrm{~g}$ of fiber and $1 \mathrm{~g}$ of protein (Song et al., 2010).

Sugarbeet is mainly a temperate crop, but for tropical region such as India, Pakistan, Bangladesh etc. the international company Syngenta developed and introduced some new sugarbeet genotypes that can be grown successfully under tropical climatic conditions which is known as "tropical sugarbeet". The optimum spacing in sugarbeet is very important to achieve high beet yields with good quality. Sugarbeet leaves development during the growing season results in more efficient use of sunlight, since it is important for the formation and expansion of canopy (Sarmadnia and Koocheki, 1997). There is a 
close relationship between yield and production of leaf area. Yield is affected by the amount of radiation received by the leaves (Fortune et al., 1999; Sarmadnia and Koocheki, 1997).

It is well known that optimum plant population density is prerequisite for high yield and quality of beets. Kashem (2014) reported from a study conducted at Gazipur that the best time for sowing of sugarbeet is early November with a spacing of $50 \mathrm{~cm} \times 20 \mathrm{~cm}$. However, more experiments are necessary to conduct in different environment to make a conclusion on determining the optimum plant spacing for maximum productivity of sugarbeet in Bangladesh. The present study was therefore, undertaken at BSRI to find out the optimum plant spacing for sugarbeet cultivation in Bangladesh.

\section{Materials and Methods}

The experiment was carried out at Agronomy and Farming Systems research field, Bangladesh Sugarcrop Research Institute during November 2012 to May 2013. The experimental field was located at $24^{\circ} 08^{\prime} \mathrm{N}$ latitude and $89^{\circ} 04^{\prime} \mathrm{E}$ longitude at an average altitude is $20 \mathrm{~m}$. The experiment comprised nine spacing viz. $50 \mathrm{~cm} \times 20 \mathrm{~cm}, 60 \mathrm{~cm} \times 20 \mathrm{~cm}, 70 \mathrm{~cm} \times 20 \mathrm{~cm}, 50 \mathrm{~cm} \times 25 \mathrm{~cm}, 60 \mathrm{~cm} \times 20 \mathrm{~cm}, 70$ $\mathrm{cm} \times 25 \mathrm{~cm}, 50 \mathrm{~cm} \times 30 \mathrm{~cm}, 60 \mathrm{~cm} \times 30 \mathrm{~cm}$ and $70 \mathrm{~cm} \times 30 \mathrm{~cm}$ with three replications in a randomized complete block design. The sugarbeet variety Cauvery was used in this experiment. The size of the unit plot was $16 \mathrm{~m}^{2}(4 \mathrm{~m} \times 4 \mathrm{~m})$. The experimental lands was ploughed well by tractor where the deep ploughing and cross ploughing were done four times followed by leveling with a ladder. The land was then uniformly fertilized with $120 \mathrm{~kg} \mathrm{~N}, 45 \mathrm{~kg} \mathrm{P}, 135 \mathrm{~kg} \mathrm{~K}, 19 \mathrm{~kg} \mathrm{~S}, 2.5 \mathrm{~kg} \mathrm{Zn}$ and $1.2 \mathrm{~kg} \mathrm{~B} \mathrm{ha}^{-1}$ (BSRI, 2011). Three weedings were done at 30, 50 and 70 DAS. Plants were thinned at the age of 35 days after sowing to obtain one plant hill ${ }^{-1}$. Earthing-up was done to cover the root base and to facilitate drainage operation. Construction and re-construction were performed during each time of weeding. The experimental field required 3 irrigations applied at 45, 90 and 125 DAS. Data collection for growth contributing components (germination percentage, number of leaves plant ${ }^{-1}$, root length, shoot length, root fresh weight, shoot fresh weight, root dry weight, shoot dry weight, crop growth rate) were done from five randomly selected plants of each plot. Root and shoot dry weight were measured through air-dry, and then oven dry at $70^{\circ} \mathrm{C}$ till constant weight obtained which were converted to $\mathrm{g} \mathrm{plant}^{-1}$. All data were statistically analyzed according to the technique of analysis of variance (ANOVA) by means of "STATISTIX-10" Computer software package for windows version (Statistix-10, 2013) and least significant difference (LSD) method was used to test the differences between treatment means at $5 \%$ level of probability.

\section{Results and Discussion}

\section{Germination percentage}

Germination percentage did not show any significant response among different spacing of tropical sugarbeet (Table 1). The maximun germination percentage (95.67\%) was obtained from the spacing 70 $\mathrm{cm} \times 30 \mathrm{~cm}$ and the minimum $(93.67 \%)$ was obtained from the spacing $70 \mathrm{~cm} \times 25 \mathrm{~cm}$.

Table 1. Germination percentage of sugarbeet as affected by spacing at 15 days after seed sowing

\begin{tabular}{cc}
\hline Treatments & Germination percentage (\%) \\
\hline $\mathrm{T}_{1}=50 \mathrm{~cm} \times 20 \mathrm{~cm}$ & 94.33 \\
$\mathrm{~T}_{2}=60 \mathrm{~cm} \times 20 \mathrm{~cm}$ & 94.67 \\
$\mathrm{~T}_{3}=70 \mathrm{~cm} \times 20 \mathrm{~cm}$ & 95.00 \\
$\mathrm{~T}_{4}=50 \mathrm{~cm} \times 25 \mathrm{~cm}$ & 94.67 \\
$\mathrm{~T}_{5}=60 \mathrm{~cm} \times 25 \mathrm{~cm}$ & 94.67 \\
$\mathrm{~T}_{6}=70 \mathrm{~cm} \times 25 \mathrm{~cm}$ & 93.67 \\
$\mathrm{~T}_{7}=50 \mathrm{~cm} \times 30 \mathrm{~cm}$ & 94.67 \\
$\mathrm{~T}_{8}=60 \mathrm{~cm} \times 30 \mathrm{~cm}$ & 95.67 \\
$\mathrm{~T}_{9}=70 \mathrm{~cm} \times 30 \mathrm{~cm}$ & 95.67 \\
\hline
\end{tabular}




\begin{tabular}{cc}
\hline $\operatorname{LSD}_{(0.05)}$ & $\mathrm{NS}$ \\
$\mathrm{CV}(\%)$ & 2.28 \\
\hline
\end{tabular}

NS = Not significant

\section{Number of leaves plant $^{-1}$}

Number of leaves plant ${ }^{-1}$ in tropical sugarbeet at different DAS was significantly influenced by spacing except at 30 DAS (Fig. 1). Leaf number increased rapidly up to 120 DAS and then decline at 150 DAS due to drying of older leaves with all the spacing. The highest number of leaves plant $^{-1}$ (34.33) was obtained from the spacing of $70 \mathrm{~cm} \times 30 \mathrm{~cm}$ which was statistically similar with $60 \mathrm{~cm} \times 30 \mathrm{~cm}$ (33.67), $50 \mathrm{~cm} \times 30 \mathrm{~cm}(33.40), 70 \mathrm{~cm} \times 25 \mathrm{~cm}(33.33), 60 \mathrm{~cm} \times 25 \mathrm{~cm}(33.07)$ and $50 \mathrm{~cm} \times 25 \mathrm{~cm}$ (31.53) spacing at 120 DAS. The lowest number of leaves plant $^{-1}(27.87)$ was obtained from $50 \mathrm{~cm} \times$ $20 \mathrm{~cm}$ which was statistically similar with $60 \mathrm{~cm} \times 20 \mathrm{~cm}(29.13)$ and $70 \mathrm{~cm} \times 20 \mathrm{~cm}$ (31.47) spacing. Number of leaves plant ${ }^{-1}$ decreased in closer spacing might be due to competition for space, nutrients, light and moisture than that of wider spacing. Theurer (1979) also reported that spacing affects sugar production.

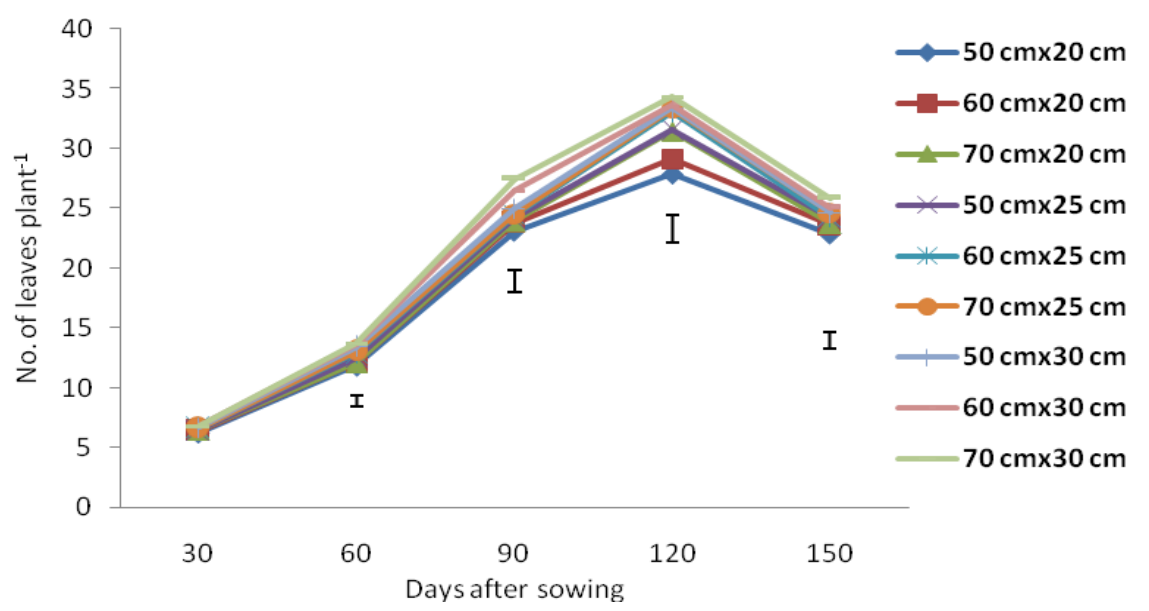

Fig. 1 Number of leaves plant ${ }^{-1}$ of sugarbeet as affected by spacing over the growth period

(Vertical bar indicates LSD at 0.05)

\section{Root and shoot length}

A significant effect of spacing was observed at different DAS for root and shoot length. Root length increased gradually up to 150 DAS (Fig. 2) and shoot length increased rapidly up to 120 DAS but decreased at 150 DAS with all the spacing (Fig. 3). The spacing $50 \mathrm{~cm} \times 20 \mathrm{~cm}$ created the maximum root length $(38.97 \mathrm{~cm})$ followed by the spacing of $60 \mathrm{~cm} \times 20 \mathrm{~cm}(38.04 \mathrm{~cm}), 70 \mathrm{~cm} \times 20 \mathrm{~cm}(37.74$ $\mathrm{cm})$ and minimum root length $(33.17 \mathrm{~cm})$ was obtained from the spacing of $70 \mathrm{~cm} \times 30 \mathrm{~cm}$ followed by the spacing $60 \mathrm{~cm} \times 30 \mathrm{~cm}(33.82 \mathrm{~cm})$ and $50 \mathrm{~cm} \times 30 \mathrm{~cm}(34.21 \mathrm{~cm})$ at 150 DAS. At 120 DAS, the highest shoot length $(54.07 \mathrm{~cm})$ was found in the spacing $70 \mathrm{~cm} \times 30 \mathrm{~cm}$ followed by the spacing 60 $\mathrm{cm} \times 30 \mathrm{~cm}(53.23 \mathrm{~cm})$ and $50 \mathrm{~cm} \times 30 \mathrm{~cm}(52.17 \mathrm{~cm})$ while the spacing of $50 \mathrm{~cm} \times 20 \mathrm{~cm}$ gave the lowest $(44.77 \mathrm{~cm})$ shoot length followed by the spacing $60 \mathrm{~cm} \times 20 \mathrm{~cm}(47.20 \mathrm{~cm})$. The general trend was a decrease in root length with the increase of wider spacing and increase in shoot length with the increase of wider spacing throughout the growth period. Pospisil et al. (2000) also reported that increasing plant population might be due to closer spacing resulted in leaf surface reduction in each plant. 


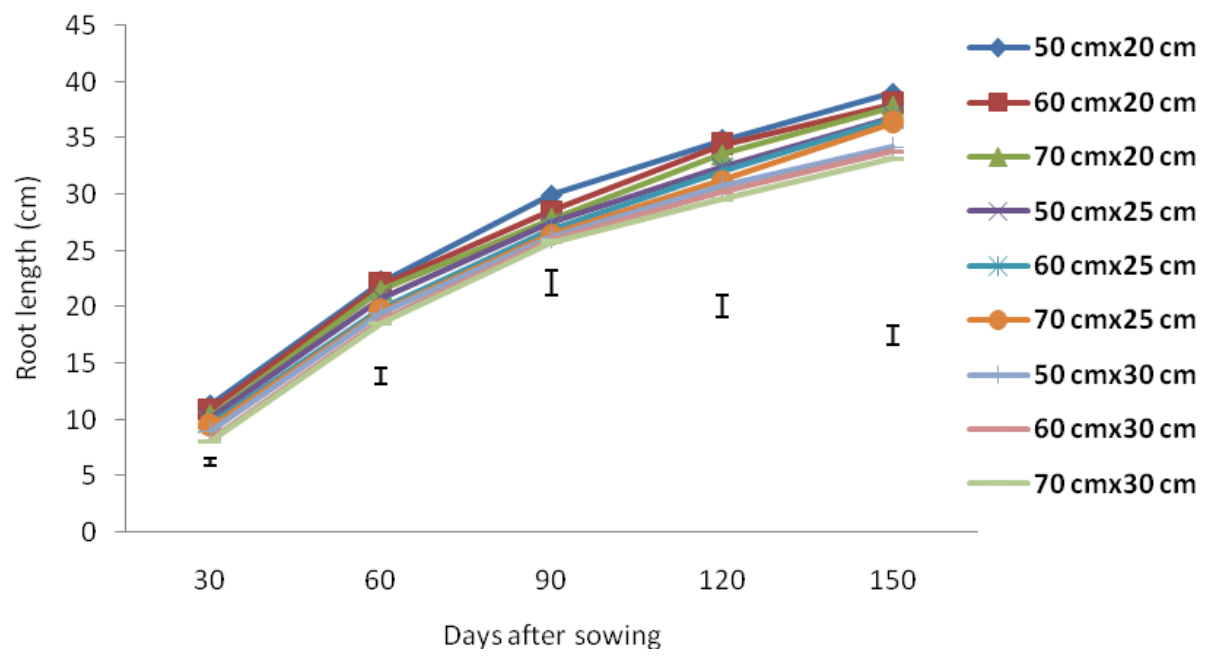

Fig. 2 Root length plant ${ }^{-1}$ of sugarbeet as affected by spacing over the growth period

(Vertical bar indicates LSD at 0.05 )

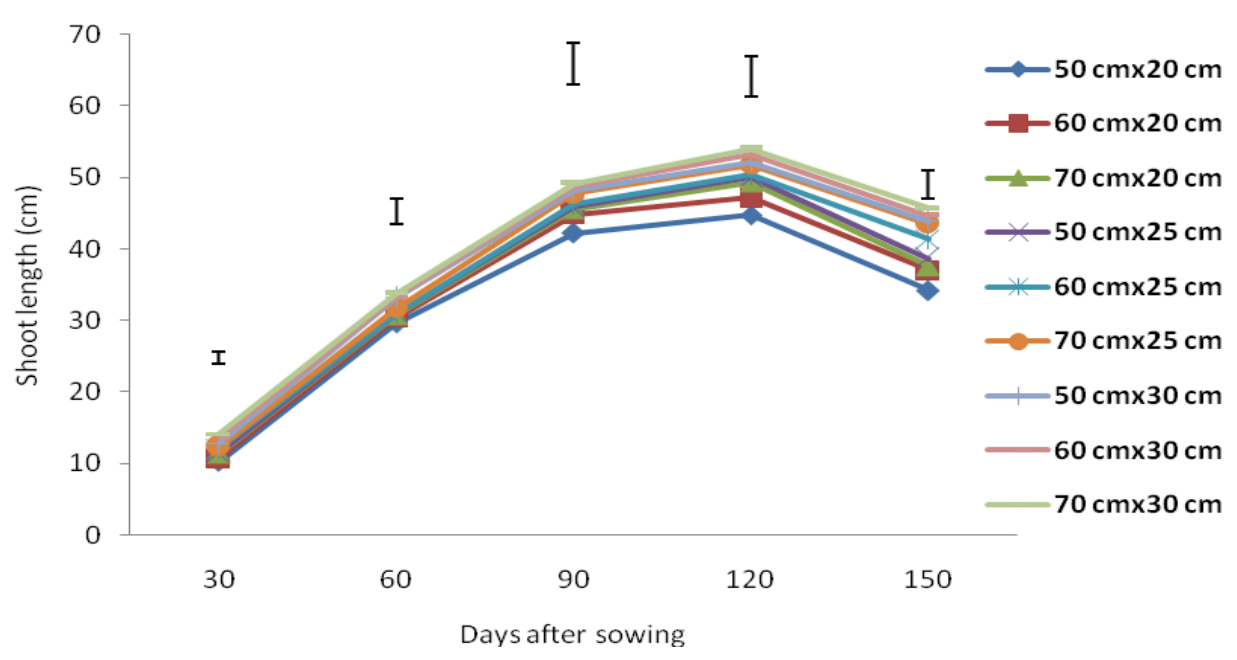

Fig. 3 Shoot length plant ${ }^{-1}$ of sugarbeet as affected by spacing over the growth period (Vertical bar indicates LSD at 0.05)

\section{Root and shoot fresh weight}

Root and shoot fresh weight plant ${ }^{-1}$ were significantly influenced by spacing throughout the growth period. The root fresh weight gradually increased from 30 to 150 DAS (Fig. 4) while the shoot fresh weight gradually increased from 30 to 120 DAS and thereafter, slightly decreased at 150 DAS with all spacing (Fig. 5). The highest root and shoot fresh weight $\left(969.47 \mathrm{~g} \mathrm{plant}^{-1}\right.$ and $\left.752.47 \mathrm{~g} \mathrm{plant}^{-1}\right)$ were obtained from $70 \mathrm{~cm} \times 30 \mathrm{~cm}$ spacing while the lowest weight $\left(691.53 \mathrm{~g} \mathrm{plant}^{-1}\right.$ and $\left.478.20 \mathrm{~g} \mathrm{plant}^{-1}\right)$ were accompanied with $50 \mathrm{~cm} \times 20 \mathrm{~cm}$ spacing, respectively. This might be due to the lowest number of leaves, lower root and shoot weight and results reveal that closer spacing decreases the crop growth throughout the growth period. These results were similar to El-Sarag (2009), who reported that the maximum root and shoot fresh weight were achieved from the lowest plant population or wider spacing $\left(46,000\right.$ plants fed $\left.{ }^{-1}\right)$. 


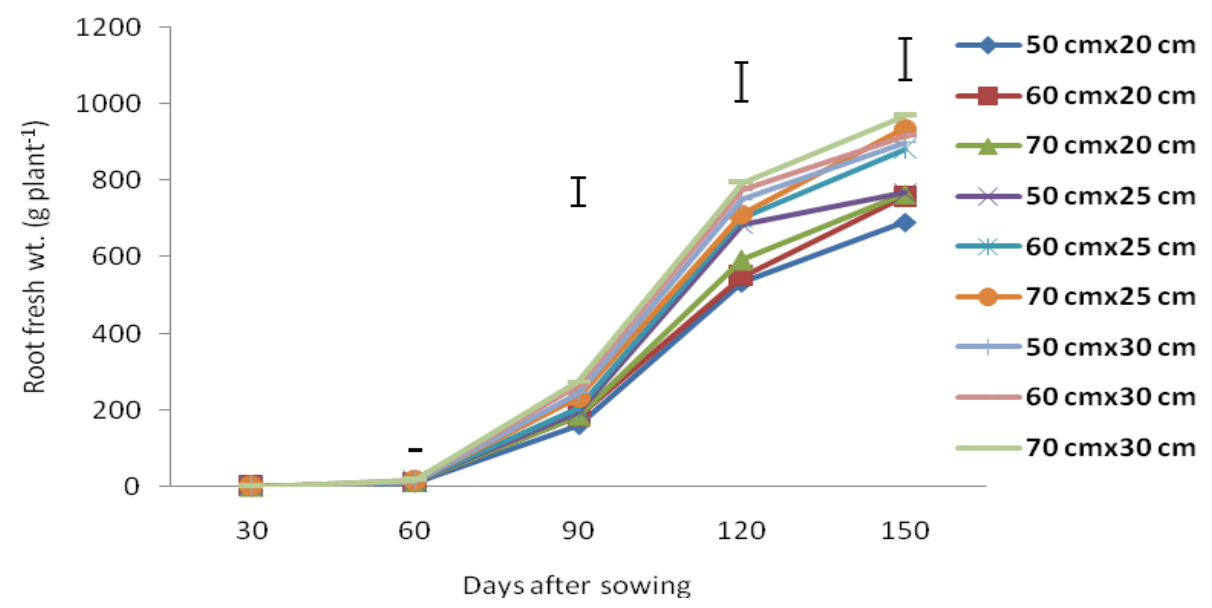

Fig. 4 Root fresh weight as of sugarbeet affected by spacing over the growth period

(Vertical bar indicates LSD at 0.05)

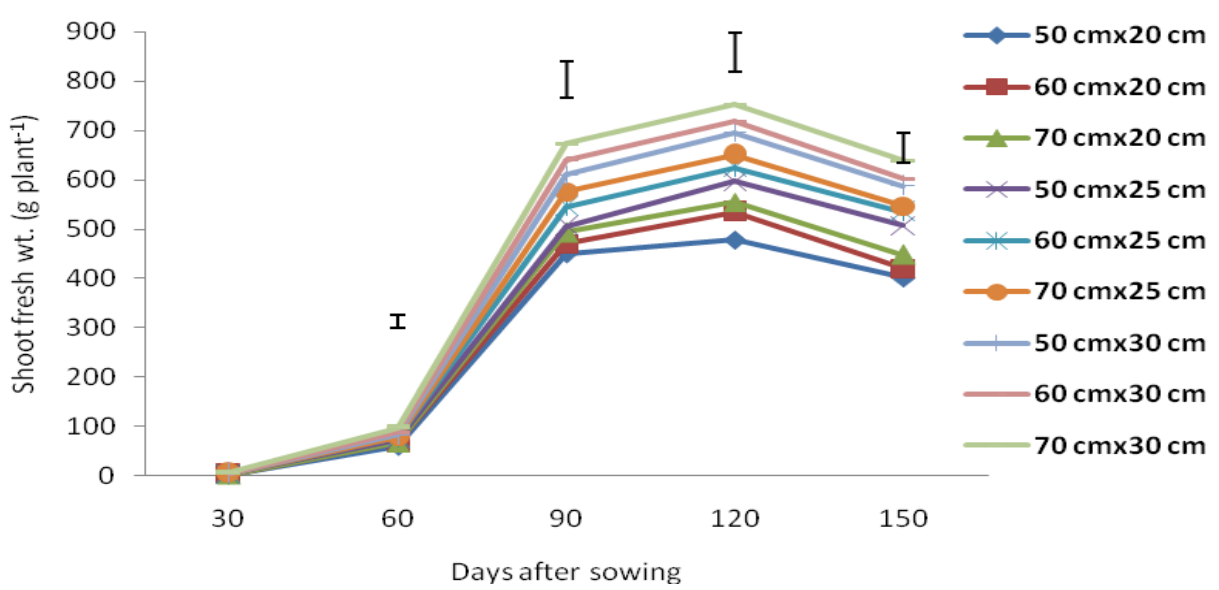

Fig. 5 Shoot fresh weight of sugarbeet as affected by spacing over the growth period

(Vertical bar indicates LSD at 0.05)

These findings also agreed with Sadre (2012), who mentioned that the increase in beet yield characters value can be explained through the fact that, the higher biomass in treatments having comparatively less plant population was possibly due to optimum utilization of soil and other environmental resources with lower competition by the crop. Heitholt and Sassenrath (2010) stated that plant populations affect most root parameters of sugarbeet even under optimal growth conditions and therefore it is considered a major factor determining the degree of competition between plants. Similar findings were also reported by Ahmad et al. (2010) and Hamidia et al. (2010).

\section{Root and shoot dry weight}

Root and shoot dry weight plant ${ }^{-1}$ were significantly influenced by spacing over the growth period. Root dry weight increased gradually up to 150 DAS (Fig. 6) and shoot dry weight increased gradually up to 120 DAS but, decreasing at 150 DAS (Fig. 7) for all the spacing. The highest root and shoot dry weight $\left(116.07 \mathrm{~g} \mathrm{plant}^{-1}\right.$ and $\left.68.42 \mathrm{~g} \mathrm{plant}^{-1}\right)$ was found with $70 \mathrm{~cm} \times 30 \mathrm{~cm}$ spacing while $50 \mathrm{~cm} \times 20$ $\mathrm{cm}$ spacing gave the lowest root and shoot dry weight $\left(102.33 \mathrm{~g} \mathrm{plant}^{-1}\right.$ and $\left.43.33 \mathrm{~g} \mathrm{plant}^{-1}\right)$, respectively. It happened due to inadequate number of plants in wider spacing and over population in 
closer spacing. It reveals that wider spacing is the best in terms of the highest root and shoots dry weight plant $^{-1}$ production.

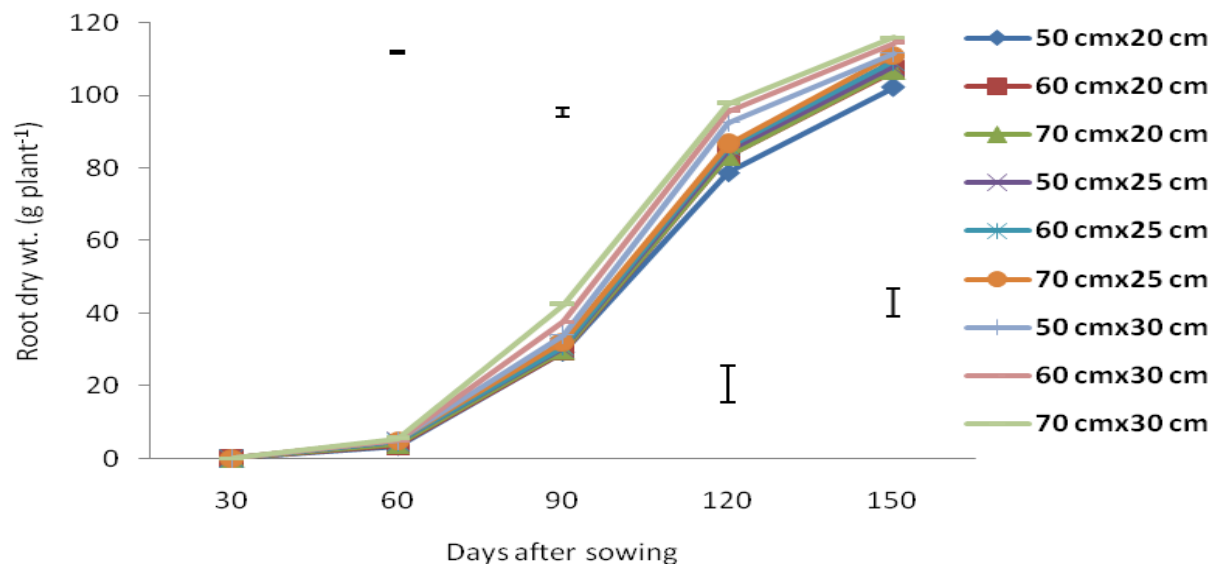

Fig. 6 Root dry weight of sugarbeet as affected by spacing over the growth period (Vertical bar indicates LSD at 0.05)

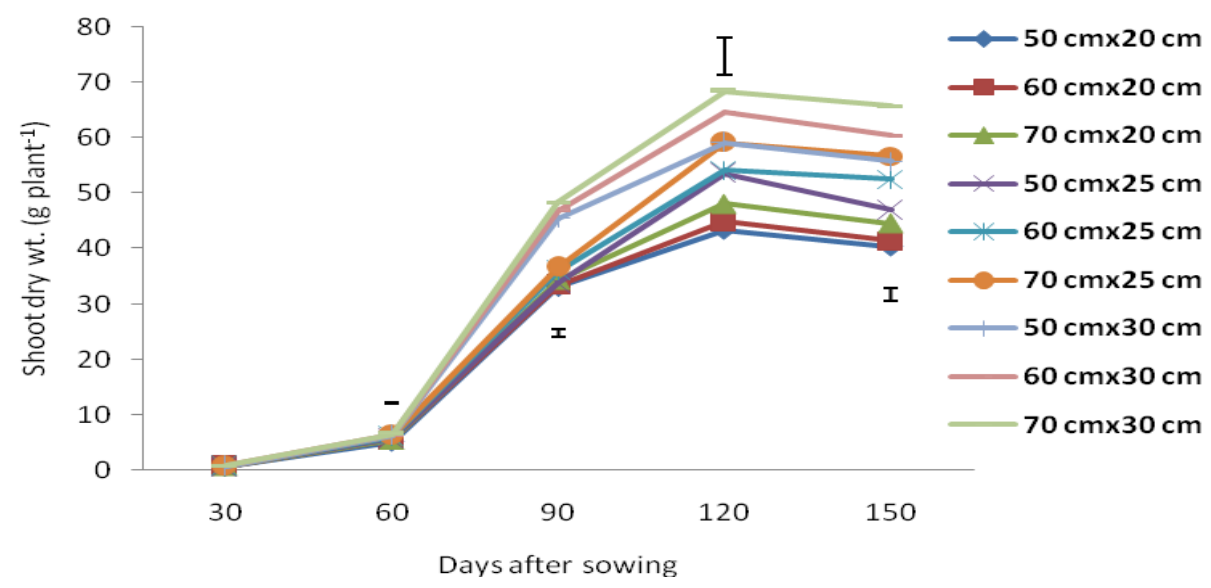

Fig. 7 Shoot dry weight of sugarbeet as affected by spacing over the growth period (Vertical bar indicates LSD at 0.05)

\section{Crop growth rate (CGR)}

Crop growth rate of tropical sugarbeet was significantly influenced by spacing at 30-60, 60-90 and 90120 DAS but insignificant variation observed at 120-150 DAS (Fig. 8). At 90-120 DAS, the highest CGR (2.56 $\left.\mathrm{g} \mathrm{day}^{-1}\right)$ was achieved from $70 \mathrm{~cm} \times 25 \mathrm{~cm}$ spacing which was statistically similar with all other spacing due to efficient utilization of environmental factors like light, air, soil nutrient, soil moisture etc. because of its optimum canopy development. Spacing of $50 \mathrm{~cm} \times 20 \mathrm{~cm}$ caused by narrow spacing lowered the CGR $\left(1.99 \mathrm{~g} \mathrm{day}^{-1}\right)$ due to competition among over populated plants. 


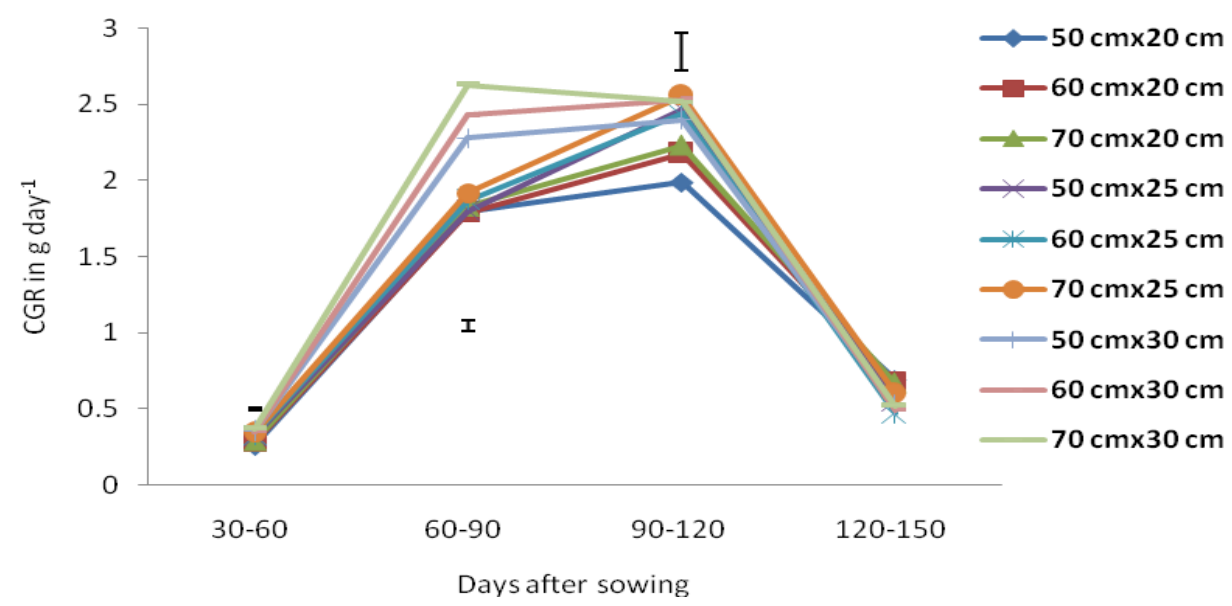

Fig. 8 Crop growth rate of sugarbeet as affected by spacing over the growth period

(Vertical bar indicates LSD at 0.05)

\section{Conclusion}

The findings of the study reflected that despite the individual plant with wider spacing of $70 \mathrm{~cm} \times 30$ $\mathrm{cm}$ produced the maximum growth of sugarbeet the spacing $50 \mathrm{~cm} \times 20 \mathrm{~cm}$ was the optimum for higher root yield.

\section{References}

Abdel-Motagally, F.M.F. and K.K. Attia. 2009. Response of sugarbeet plants to nitrogen and potassium fertilization in sandy calcareous soil. Int. J. Agric. Bio. 11: 695-700.

Ahmad, Z.P., K.M. Shah, H. El-Sharkawi, P.B.S. Gama, E.A. Khan, T. Honna and S. Yamamoto. 2010. Sugarbeet (Beta vulgaris L.) response to different planting methods and row geometries II: Effect on plant growth and quality. J. Food Agric. Envir. 8(2): 785-791.

BSRI. 2011. Sugarbeet cultivation in Bangladesh. Bangladesh Sugarcrop Research Institute. Ishurdi, Pabna, Bangladesh. p.4.

El-Sarag, E.I. 2009. Maximizing sugarbeet yield, quality and water use efficiency using some agriculture practice under North Sinai conditions. Suez Canal University, Egypt. Bull. Fac. Agric. Cairo Univ. 60: 2-13.

Fortune, R.A., J.I. Burke, T. Kennedy and E. O’Sullivan. 1999. Effect of early sowing on the growth, yield and quality of sugarbeet. J. Field Crops Res. 19: 3-17.

Hamidia, A., N. Khodabandehb and A.D. Mohammadynasabc. 2010. Plant density and nitrogen effects on some traits of maize (Zea mays L.). Plant Ecophys. 2: 47-52.

Heitholt, J.J. and G.F. Sassenrath. 2010. Inter-Plant Competition: Growth responses to plant density and row spacing physiology of cotton. pp.179-186.

Kashem, M.N. 2014. Effect of sowing date, spacing, nitrogen and potassium on growth, yield and quality of tropical sugarbeet. Ph. D. Thesis, Fac. Agron., BSMRAU Univ., Gazipur, Bangladesh.

Patil, A.S. and K.A. Patil. 2011. Production consumption and deficit of sugar at global level in 2010-11 and 2011-12 a forecast www.ibap.

Pospisil, M., A. Pospisil and M. Rastija. 2000. Effect of plant density and nitrogen rates upon the leaf area of seed sugarbeet on seed yield and quality. Euro. J. Agron. 12: 69-78. 
Sadre, P. A. Soleymani and H.R. Javanmard. 2012. Root Yield and quality traits of sugarbeet (Beta vulgaris $\mathrm{L}$.) in relation to nitrogen fertilizer and plant density in isfahan region. Int. J. Agric. Crop Sci. 4(20): 1504-1507.

Sarmadnia, G.H. and A. Koocheki. 1997. Crops Physiology. Publications of Mashhad University Jahad, Iran.

Shahl, I.H., N.U. Khanl, G. Flasool and N. Saeed. 2000. Effect of sowing time and plant population on root yield and accumulation of sugar in sugarbeet. Pak. J. Bio. Sci. 3(12): 2005-2007.

Sohrabi, Y. and G. Heidari. 2008. Influence of withholding irrigation and harvest times on yield and quality of sugarbeet (Beta vulgaris). Intl. J. Agric. Biol. 10: 427-431.

Song, W., C.M. Derito and M.K. Liu. 2010. Cellular antioxidant activity of common vegetables. J. Agric. Food Chem. 58(11): 6621-6629.

Statistix 10. 2013. Analytical Software. Tallahassee, Florida, USA.

Syngenta. 2004. Syngenta Bangladesh Ltd. http// Sugarbeet.ucdavis.edu/ SBPM/Nutrients/ fig1. GIF. www.Sugarproducer.com, 2011. Sugar Producer Magazine.

Theurer, J.C. 1979. Growth Patterns in Sugarbeet Production. J. Americ. Soc. Sugarbeet Tech. 20(4): 343367. 